\title{
The state of health services partnering with consumers: evidence from an online survey of Australian health services
}

\author{
Jane Farmer ${ }^{1 *}$ (D) Christine Bigby ${ }^{2}$, Hilary Davis ${ }^{2,3}$, Karen Carlisle ${ }^{4,5}$, Amanda Kenny $^{6}$ and Richard Huysmans ${ }^{7}$
}

\begin{abstract}
Background: Involving consumers in producing health services is mandated in many countries. Evidence indicates consumer partnerships lead to improved service design, quality and innovation. Involving participants from minority groups is crucial because poor understanding of distinctive needs affects individuals' service experiences and outcomes. Few studies consider service compliance with consumer partnering requirements or inclusion of minority group participants.

Methods: An online survey structured by domains of the Australian National Safety and Quality in Health Service Standards (NSQHS, 2013), was conducted. Questions covered consumer partnering in service planning, management and evaluation plus patient care design and inclusion of consumers from minority groups. Approximately 1200 Australian hospital and day surgery services were identified and 447 individual email addresses were identified for staff leading consumer partnerships. Quantitative data were analysed using SPSS. Qualitative responses, managed in NVivo, were analysed thematically. Frequencies were produced to indicate common activities and range of activities within question domains.
\end{abstract}

Results: Comprehensive responses were received from 115 services (25.7\%), including metropolitan and nonmetropolitan, private and public service settings. Most respondents (95.6\%) "partnered with consumers to develop or provide feedback on patient information". Regarding inclusion of participants from minority groups, respondents were least likely to specifically include those from socially disadvantaged backgrounds (23.6\%). Public health services were more likely than private services to engage with consumers.

Conclusions: The survey is the first to include responses about consumer partnering from across Australia. While many respondents partner with consumers, it is clear that more easily-organised activity such as involvement in existing committees or commenting on patient information occurs more commonly than involvement in strategy or governance. This raises questions over whether strategic-level involvement is too difficult or unrealistic; or whether services simply lack tools. Minority views may be missed where there is a lack of specific action to include diversity. Future work might address why services choose the activities we found and probe emerging opportunities, such as using social media or online engagement.

\footnotetext{
* Correspondence: jcfarmer@swin.edu.au

${ }^{1}$ Social Innovation Research Institute, Swinburne University of Technology,

John Street, Hawthorn, Melbourne, Australia

Full list of author information is available at the end of the article
}

(c) The Author(s). 2018 Open Access This article is distributed under the terms of the Creative Commons Attribution 4.0 International License (http://creativecommons.org/licenses/by/4.0/), which permits unrestricted use, distribution, and reproduction in any medium, provided you give appropriate credit to the original author(s) and the source, provide a link to the Creative Commons license, and indicate if changes were made. The Creative Commons Public Domain Dedication waiver (http://creativecommons.org/publicdomain/zero/1.0/) applies to the data made available in this article, unless otherwise stated. 


\section{Background}

Involving consumers in producing health services is mandated in many countries. Evidence indicates consumer partnerships lead to improved service design, quality and innovation [1].

Since the seminal 1978 Declaration of Alma Ata [2], it has become widely accepted that citizens have both rights and duties to participate in planning and implementing their health care and there has been a shift towards recognising clinicians, managers, consumers and carers as partners in the health system [3].

Participation of consumers from diverse backgrounds is critical in partnering with consumers as one way of ensuring health services understand the distinctive needs of minority groups [4]. While health services accreditation systems - e.g. in Australia, the National Safety and Quality in Health Service Standards (NSQHS) - require health organisations to involve consumers, [5] there have been few large-scale studies, across health systems, of how accreditation and standards affect consumer partnership activities. This is significant as grandiose aims for consumer involvement are suggested, including from informing day-to-day service provision (to improve services) through to roles in governance and driving strategy (implying a deep and wide relationship inside health agencies) [6, 7]. Our study considers the state of the art of consumer partnership as defined in the NSQHS standards [5] in Australia, in 2017. The standards cover all health service organisations that provide 'hospital and day service procedures' [see: www.safetyandquality.gov. au/our-work/assessment-to-the-nsqhs-standards/infor mation-for-accrediting-agencies/] which includes 'a wide variety of health service organisations...[of]... variable size, structure and complexity of health service delivery models' ([8], p.3). The study comprised a survey of these Australian health services' activities in partnering with consumers. In particular, we probed whether and how, health services partner with minority groups including people from diverse cultural and ethnic backgrounds, Indigenous Australians and people with disabilities.

Health services standards indicate what is prioritised in a health system and what is considered fundamental to consumer safety and quality of experience. In an overloaded system, standards signal to management and staff what must be done and not just what could be done. Inclusion of consumer partnering as a standard, therefore, highlights this as central rather than optional, to service delivery. Standard Two of the ten domain, Australian NSQHS [3] concerns partnering with consumers. It lists a range of activities in which consumers should be involved, including service planning, designing care, management and evaluation. The necessity to involve a diverse group of people from across the community is also highlighted so the needs of all potential service users can inform decision-making. Given the growing sophistication of advice about implementing consumer partnerships - for example, NHS England [7] has a new suite of evidence-based patient and public involvement guidance - we considered it timely to study how services across Australia partner with consumers and the barriers experienced. This evidence will identify weaknesses and areas requiring further development to be tackled by policymakers, practitioners and researchers. While our survey was of Australian services, findings are relevant internationally in highlighting challenges of embedding consumer partnership systemically and in identifying examples of good practice.

Consumer partnering covers 'patients, families, carers and other support people' ([5]; p.5); a group that might be considered 'experts by experience' ([7]; p.6). The concept of consumer partnering aligns with international movements [9], including English policy on patient and public involvement [5] and Canadian policy on including citizen views in health system and policy planning and decision-making [10]. Signalling the inherent dualistic nature of the relationship between services and citizens in these partnering activities, the Australian NSQHS standard states consumers: 'have the right and duty to participate individually and collectively in the planning and implementation of their health care' ([5] p.6).

Given the significance of consumer partnerships, health service managers must ensure they occur [11]. Gill and Gill [12] suggest that implementing consumer partnering in health can be challenging as it requires staff moving from positions of power to 'involved egalitarian relationships' with consumers, requiring that 'professionals must relinquish control as consumers accept greater responsibility'. However, as Taylor ([13] pp.114117) notes, 'instrumental' partnering instigated by managers and staff still leaves it a 'top-down' process essentially implemented to achieve service goals, in contrast with 'bottom-up' citizen activism.

An early evaluation of the Australian standard on consumer partnering found that 'consulting with consumers to provide feedback on patient publications' was considered the easiest way to partner by health service respondents [14]. The evaluation found that partnering was challenging, with involvement in governance considered particularly difficult. Understanding the purpose of partnering, obtaining executive endorsement, and strategies for implementation were also raised as problematical issues. The evaluation did not probe diversity of consumers involved - an area frequently raised as challenging in the literature [15].

NHS England produced guidance for health services to assist them with identifying strategies and resources for inclusion of different minority groups in consumer 
partnerships [16]. This was intended to move partnering from the traditional tendency to engage mainly from 'snowy white peaks' [17]. The English guidance summarises evidence about effective strategies for engaging with different minority groups or adapting general engagement to better include people from minority groups. De Freitas and Martin [4] highlight that inclusion of minority voices is important in exposing health practitioners to alternative understandings of health and healthcare that challenge dominant mainstream thinking. NHS England [16] defines minority groups as those protected by the Equality Act of 2010 [18], including those who experience inequality due to disability, race, ethnicity or sexual orientation. In our study we were particularly interested to probe strategies being used by Australian health services to partner with diverse community members. Henceforth, we use the term 'minority groups' to encompass a range of social groups recognized as experiencing exclusion.

As well as simply providing a range of perspectives, inclusion of minority voices is imperative for community health improvement. Minority groups, tend to have poorer health outcomes associated with environmental, socio-demographic or individual characteristics [19]. Examining causal pathways of health gaps, Trollor and colleagues [20] highlight that, for people with an intellectual disability, lack of knowledge and awareness within health systems and lack of advocacy underpins poor service adaptation for their needs. In turn, this reflects in the high rate of hospital readmissions and avoidable deaths for people with an intellectual disability. Similarly, Shimmin and colleagues [21] examined health service experiences of socio-economically disadvantaged Canadians, including people from Indigenous and migrant backgrounds. They raised, in particular, poor understanding within the health system of consumers who had experienced trauma, and the few adjustments to take account of those with trauma histories which influenced engagement with health services and compounded poor health status. Partnering with participants of minority groups and using their experiences to inform service provision, is therefore likely to produce significant benefits in improving services for all consumers. Affirmative action to include minority participants may also counterbalance the tendency of these groups not to complain [22], which can mean their health challenges are seldom raised, and often neglected.

Involvement in public meetings or committees tend to be ineffective strategies for including minority groups as they can be intimidating for those with low confidence or communication difficulties [23, 24]. Those who fear stigma are unlikely to volunteer in health partnering; for example, reticence of LGBTI people to come forward due to feelings of isolation, insecurity and low trust in health services has been found [25]. So, considerable effort needs to be invested in building a secure and positive health organisation context. Partnering can be operationally difficult, requiring alternative ways for participant involvement such as allocating specific time in meetings, allowing for skype or telephone participation, for supporters, peers or translators to be present or different ways of expression for people with communication challenges [16].

A strand in the literature warns health services against trying to include every possible type of consumer as no-one can be representative of their entire social group or defined by one set of characteristics [26]. Nonetheless, attracting members of minority groups whose health experiences are unlikely to be represented by others is crucial. Frawley and Bigby [23] suggest progress has been made to include people with a disability on boards, advisory committees and reference groups in health, but under-representation persists.

Our study explored strategies and activities health service managers deploy to partner with consumers by surveying a comprehensive population of Australian health services that provide hospital or day surgery services. We aimed to characterise partnering activities, identify how health services recruit consumers, and the extent to which minority groups were included. The research questions were 1) what is the state of consumer partnership in Australian health services? And, 2) to what extent do Australian health services make efforts to include minority groups in partnership? Using an online survey, we asked about activities described in the NSQHS Standard Two 'Partnering with Consumers' [3]. Australian hospital and day surgery services are all accredited against these and thus they indicate the 'gold standard' of what health services should be enacting. This study obtained ethical approval from the La Trobe University Human Research Ethics Committee (S16-129).

\section{Methods}

We designed and applied an online questionnaire, targeted at hospital and day surgery services, that asked a set of questions covering all of the activities for consumer partnering suggested in the Australian NSQHS standards [5]. These are structured in three domains in the standards: service planning; patient care design; and service management and evaluation. The standards also note the significance of including people from diverse backgrounds so we included a set of questions about inclusion of minority groups [16]. The questionnaire text is available as an Additional file 1. The questionnaire was built using Qualtrics (https://www.qualtrics.com/), and was targeted at Chief Executive Officers (CEOs) of health services or other staff members responsible for service quality and safety accreditation. Replies to the 
questionnaire were anonymous. This form of survey is a cost-effective way of reaching respondents scattered across a wide geographic area. Closed questions provided a pre-defined set of responses plus there was space for comments. Response rates to online surveys have tended to be lower than for postal surveys [27] but we pre-identified participants, so we aimed for a $25 \%$ response rate overall, which was met.

\section{Sample}

We took a whole of population approach and used the Australian Hospitals and Aged Care Database to identify services (see http://jpmmedia.com.au/directmarketing/hospitals-aged-care-database/about-hospitals-aged-care-database/). To ensure questionnaires were directly sent to the most suitable participant, we telephoned all health organisations to identify an appropriate personal, rather than general organisation, email address. Criterion for inclusion was that the participant was either a) the CEO or equivalent of a participating health service, b) CEO representative (nominated by the CEO), or c) the person in charge of accreditation (and the NSQHS Standard Two specifically) for the particular health service. One participant/return only, from each emailed address was requested to avoid multiple responses from the same service. While compiling the sample, we found some CEOs have responsibility for multiple health service organisations. We noted these in our database and decided to send each of these CEOs only one email. This was to avoid confusion about distinguishing between health services when surveys were returned. After deducting duplicates, health services that had closed or merged, and those covered by a 'parent' health service organisation responsible for accreditation, we identified a total of 447 individual participant email addresses, covering 1200 health services in total.

\section{Data collection}

The survey (see Additional file 1) was designed to collect data to address the two research questions. Demographic data, including about the state or territory location, respondent job title, and service type, were collected. For type we devised a classification aligned with Australian health services that provide hospital or day surgery services: i.e. publicly-funded, publicly-funded community health service, metropolitan, regional, sub-regional, small rural, multi-purpose, community-based, private hospital or other (asking respondents to specify). We devised this typology based on testing of survey drafts with four health service managers. Australian states have different categorisations for health service types so we devised a typology intended to be useable across Australia.
Questions to address Research Question 1 followed the activities for consumer partnering identified within domains of NSQHS Standard Two; for example, within the domain 'service management and evaluation', questions included: "Have you used consumers in the analysis of safety and quality performance information and data, to develop plans for your health service?" and "Have you partnered with consumers in the analysis of patient feedback data?". Responses could be: yes, no or don't know, followed by a request for explanation (e.g. briefly list how you have done this). To address Research Question 2, we included a set of minority groups likely to have particular needs or perspectives based on their experiences. We based these on categories from a NHS England document [16]. We asked respondents if their services had "specifically sought to include" each of the specified minority groups. The survey asked how health services recruited consumers from these groups; or if not, then why. Finally, a box was provided where respondents could record anything else on the topic that they wanted to say.

Survey questions and format were loaded into Qualtrics. A link to the survey was sent by email to the identified participants. The email included an introduction letter, plain language information sheet and ethics statements. Once the plain language statement was read, the survey took about 15 min to complete. Consent was obtained via response to the survey. All surveys were returned anonymously via Qualtrics. The survey was first emailed in September 2016 (69 surveys completed), with follow-up reminders in October 2016 (43); and two in November 2016 (33 and seven). We undertook to send all participants a findings summary at study end.

\section{Data analysis}

Quantitative survey data were input into SPSS (IBM Version 23) and exploratory analysis conducted to examine respondent characteristics and frequencies of responses. Simple cross tabulations and Chi-square tests were calculated to determine associations between health service type (private versus public) and geographic location (metropolitan versus non-metropolitan) and service engagement in consumer partnership activities. Qualitative responses were input into NVivo (Version 11). These tended to be brief and note-like rather than discursive, due to the nature of the survey response format requested (i.e. 'please list...'). Inductive analysis was conducted to identify thematic categories. Data were then allocated to thematic categories and frequencies of quotes on themes counted [28]. KC conducted initial qualitative analyses. The other authors also read the data. JF checked and verified the analysis. 


\section{Results}

A total of 447 participants, each responding for one or more health services were contacted to participate. Responses were returned by 152 , giving a $34 \%$ response rate. Thirty-seven surveys were excluded from analysis due to responding only to Section 1: demographic data. Thus, the final number of complete, eligible survey responses was 115 (25.7\% response rate). As Table 1 shows, the largest proportion of these indicated their service was located in a metropolitan area (54.8\%), and proportions of respondents from private and public health services were similar, $46.9 \%$ private and $52.1 \%$ public.

\section{Consumer partnering activities}

Table 2 shows the number of all health services that stated they were engaged in the consumer partnering activities covered in the questionnaire (i.e. that responded yes their service has undertaken this activity). Responses are broken down by type (private and public) and geographic location (metropolitan and non-metropolitan). Due to the nature of the sample, none of the health services are specifically primary care services, although some of the services may provide primary care as part of their service portfolio. There are no specific Aboriginal and Torres

Table 1 Characteristics of respondents

\begin{tabular}{lll}
\hline $\begin{array}{l}\text { Characteristics of health } \\
\text { service of respondent }\end{array}$ & N in sample & N of respondents (\%) \\
\hline Location of service & 283 & $63(54.8)$ \\
Metro & 164 & $46(40.0)$ \\
Non-Metro & - & 6 \\
Missing or unsure & 447 & 115 \\
Total & & \\
Type of service & 172 & $60(52.1)$ \\
Public & 275 & $54(46.9)$ \\
Private & - & 1 \\
Missing & 447 & 115 \\
Total & & \\
Response by state & 7 & $2(1.7)$ \\
Australian Capital Territory & 126 & $27(23.5)$ \\
New South Wales & 5 & $2(1.7)$ \\
Northern Territories & 52 & $8(7)$ \\
South Australia & 12 & $3(2.6)$ \\
Tasmania & 66 & $14(12.2)$ \\
Queensland & 151 & $50(43.5)$ \\
Victoria & 28 & $9(7.8)$ \\
Western Australia & 447 & 115 \\
Total & & \\
\hline
\end{tabular}

Strait Islander hospital or day surgery services, but some hospitals responded that we can infer would have high use by the Aboriginal and Torres Strait Islander community.

Exploratory descriptive analysis showed that, overall, the majority of respondents reported their health services were engaged in partnering activities. The proportions of services engaged in these activities ranged from $95.6 \%$ of respondents partnering with consumers 'to develop or provide feedback on patient information', to $61.3 \%$ partnering with consumers 'to develop information about health service safety and quality performance'. Chi-square tests of association showed a significant association between type of service - public - and engagement in: strategic and operational services planning, governance structures, service design and analysis of safety and quality performance data (in bold see Table 2). Chi-square tests were calculated to determine if there was an association between metropolitan or non-metropolitan location, and partnering activities. Analysis showed only one significant association between location of service - non-metropolitan - and engagement of consumers in analysis of patient feedback data (in bold see Table 2).

\section{Partnering involving minority groups}

The survey asked about inclusion of people from minority groups in consumer partnering. Descriptive analysis indicated that specific steps to include the minority groups listed occurred for less than half of responding services (see Table 3). People from different cultural and ethnic backgrounds was the most frequently reported group that services sought to include $(45.5 \%)$. Socially disadvantaged people was the least reported group (23.6\%). Responses are broken-down by type (private and public) and geographic location (metropolitan and non-metropolitan). Chi-square tests showed a significant association between service type - public - and services seeking to include all of the minority groups described, except people of different genders (in bold Table 3). There was a significant association between location metropolitan - and seeking to include people from different cultural and ethnic backgrounds and people from the LGBTI community (in bold Table 3).

\section{Qualitative responses: partnering activities}

As noted previously, due to the nature of the questionnaire format (where participants were asked to 'list', for example, activities or reasons for doing/not doing, activities), qualitative responses tended to short, note format, rather than discursive format. This type of response lent itself to compiling frequencies of responses by theme, rather than writing summaries of each theme. Table 4 thus provides frequencies of partnering mechanisms reported (see Table 4); and Table 5 descriptions of 
Table 2 Number of respondents of health services that reported engagement in consumer partnering activities

\begin{tabular}{|c|c|c|c|c|c|c|c|}
\hline \multirow[t]{2}{*}{ Activity } & \multirow{2}{*}{$\begin{array}{l}\text { Total number } \\
\text { of services } \\
\text { responded } \\
\text { yes (\%) }\end{array}$} & \multicolumn{3}{|c|}{ Breakdown by type of service } & \multicolumn{3}{|c|}{ Breakdown by location } \\
\hline & & $\begin{array}{l}\mathrm{N} \text { Private services } \\
\text { responded yes (\%) }\end{array}$ & $\begin{array}{l}\mathrm{N} \text { Public services } \\
\text { responded yes (\%) }\end{array}$ & $\begin{array}{l}\text { Chi-square } \\
\text { test of } \\
\text { association }\end{array}$ & $\begin{array}{l}\mathrm{N} \text { Metro services } \\
\text { responded yes (\%) }\end{array}$ & $\begin{array}{l}N \text { Non-Metro } \\
\text { service responded } \\
\text { yes (\%) }\end{array}$ & $\begin{array}{l}\text { Chi-square } \\
\text { test of } \\
\text { association }\end{array}$ \\
\hline \multicolumn{8}{|c|}{ Consumer partnering in service planning } \\
\hline $\begin{array}{l}\text { To develop or } \\
\text { provide feedback } \\
\text { on patient } \\
\text { information }\end{array}$ & $109(95.6)$ & $53(96.4)$ & $56(94.9)$ & $\begin{array}{l}\text { Not } \\
\text { calculated }^{a}\end{array}$ & $61(96.8)$ & $39(95.1)$ & $\begin{array}{l}\text { Not } \\
\text { calculated }^{\mathrm{a}}\end{array}$ \\
\hline $\begin{array}{l}\text { In quality } \\
\text { improvement } \\
\text { activities }\end{array}$ & $94(84.7)$ & $47(88.7)$ & $47(81.0)$ & $1.25 p=.264$ & $54(90.0)$ & $32(78.0)$ & $2.97 p=.085$ \\
\hline $\begin{array}{l}\text { In decision making } \\
\text { about safety and } \\
\text { quality }\end{array}$ & $91(79.1)$ & $42(76.4)$ & $49(81.7)$ & $0.49 p=.485$ & $49(77.8)$ & $35(83.3)$ & $0.38 p=.535$ \\
\hline $\begin{array}{l}\text { Provided training } \\
\text { in partnering with } \\
\text { health service }\end{array}$ & $86(76.1)$ & $37(69.8)$ & $49(81.7)$ & $2.17 p=.140$ & $46(75.4)$ & $32(76.2)$ & $0.01 p=.936$ \\
\hline $\begin{array}{l}\text { In strategic and } \\
\text { operational services } \\
\text { planning }\end{array}$ & $78(69.3)$ & $27(50.0)$ & $52(86.7)$ & $\begin{array}{l}17.96 \\
p<.000\end{array}$ & $39(62.9)$ & $31(73.8)$ & $1.46 p=.227$ \\
\hline $\begin{array}{l}\text { Governance } \\
\text { structures to } \\
\text { facilitate partnering }\end{array}$ & $78(68.4)$ & $31(57.4)$ & $47(78.3)$ & $\begin{array}{l}5.76 \\
p=.016\end{array}$ & $40(63.5)$ & $29(70.7)$ & $1.61 p=.281$ \\
\hline \multicolumn{8}{|c|}{ Consumer partnering in designing care } \\
\hline $\begin{array}{l}\text { Implemented } \\
\text { training for staff } \\
\text { about consumer } \\
\text { partnering }\end{array}$ & $89(78.1)$ & $41(75.9)$ & $48(80)$ & $0.28 p=.600$ & $49(77.8)$ & $34(81.0)$ & $0.11 p=.737$ \\
\hline $\begin{array}{l}\text { Used consumers in } \\
\text { service design }\end{array}$ & $77(67.5)$ & $31(57.4)$ & $46(76.7)$ & $\begin{array}{l}4.81 \\
p=.028\end{array}$ & $44(69.8)$ & $29(69.0)$ & $0.07 p=.785$ \\
\hline $\begin{array}{l}\text { Involved consumers } \\
\text { in training the clinical } \\
\text { workforce }\end{array}$ & $72(63.2)$ & $31(57.4)$ & $41(68.3)$ & $1.45 p=.227$ & $43(68.3)$ & $24(57.1)$ & $1.57 p=.209$ \\
\hline \multicolumn{8}{|c|}{ Consumer partnering in service management \& evaluation } \\
\hline $\begin{array}{l}\text { Analysis of patient } \\
\text { feedback data }\end{array}$ & $81(73.0)$ & $34(65.4)$ & $47(79.7)$ & $2.86 p=.091$ & $42(66.7)$ & $36(85.7)$ & $\begin{array}{l}4.57 \\
p=.033\end{array}$ \\
\hline $\begin{array}{l}\text { Analysis of safety \& } \\
\text { quality performance } \\
\text { information \& data }\end{array}$ & $73(65.8)$ & $29(55.8)$ & $44(74.6)$ & $\begin{array}{l}4.34 \\
p=.037\end{array}$ & $44(69.8)$ & $26(61.9)$ & $0.55 p=.456$ \\
\hline $\begin{array}{l}\text { Develop information } \\
\text { about the health } \\
\text { service safety } \\
\& \text { quality } \\
\text { performance }\end{array}$ & $68(61.3)$ & $28(53.8)$ & $40(67.8)$ & $2.27 p=.132$ & $39(61.9)$ & $27(64.3)$ & $0.01 p=.904$ \\
\hline
\end{tabular}

Percentages for each survey item were calculated as valid percentage i.e. missing values were excluded

${ }^{a}$ Chi squared calculated only if all expected cell frequencies are $\geq 5$

partnering activities, along with verbatim exemplar illustrations of items listed.

The most common mechanisms listed were community advisory committees and consumer representation on other health service committees. The most common activities of community advisory committees were reviewing and providing feedback on patient data, safety and quality data and patient information. A small number of comments indicated that some health services included their advisory committee in service decision-making. The committee that consumers were most likely to attend as representatives was 'quality and risk'/ 'quality and safety'.

\section{Qualitative responses: inclusion of minority groups}

There were 160 qualitative responses to questions about including people from minority groups. Table 6 summarises the ways respondents "sought to include" participants, with illustrative comments. Some 
Table 3 Number of respondents of health services that reported seeking to include particular groups in consumer partnering

\begin{tabular}{|c|c|c|c|c|c|c|c|}
\hline \multirow{2}{*}{$\begin{array}{l}\text { Particular social groups } \\
\text { health services sought } \\
\text { to include in consumer } \\
\text { partnering }\end{array}$} & \multirow{2}{*}{$\begin{array}{l}\text { Total number of } \\
\text { services responded } \\
\text { yes (\%) }\end{array}$} & \multicolumn{3}{|c|}{ Breakdown by type of service } & \multicolumn{3}{|c|}{ Breakdown by location } \\
\hline & & $\begin{array}{l}\text { N Private } \\
\text { services } \\
\text { responded } \\
\text { yes (\%) }\end{array}$ & $\begin{array}{l}\mathrm{N} \text { Public } \\
\text { services } \\
\text { responded } \\
\text { yes (\%) }\end{array}$ & $\begin{array}{l}\text { Chi-square } \\
\text { test of } \\
\text { association }\end{array}$ & $\begin{array}{l}\text { N Metro } \\
\text { services } \\
\text { responded } \\
\text { yes (\%) }\end{array}$ & $\begin{array}{l}\text { N Non-Metro } \\
\text { service } \\
\text { responded } \\
\text { yes (\%) }\end{array}$ & $\begin{array}{l}\text { Chi-square } \\
\text { test of } \\
\text { association }\end{array}$ \\
\hline $\begin{array}{l}\text { People of different } \\
\text { cultural and ethnic } \\
\text { backgrounds }\end{array}$ & $50(45.5)$ & $18(34.6)$ & $32(55.2)$ & $4.67 p=.031$ & $34(54.0)$ & $14(33.3)$ & $3.94 p=.047$ \\
\hline Indigenous Australians & $45(41.3)$ & $11(21.6)$ & $34(58.6)$ & $15.37 p<.000$ & $28(45.2)$ & $16(38.1)$ & $0.71 p=.392$ \\
\hline $\begin{array}{l}\text { People with mental } \\
\text { health or psycho-social } \\
\text { issues }\end{array}$ & $42(38.9)$ & $12(23.5)$ & $30(52.6)$ & $9.59 p=.002$ & $25(41.0)$ & $14(33.3)$ & $0.17 p=.673$ \\
\hline $\begin{array}{l}\text { People with different } \\
\text { levels of physical or } \\
\text { sensory disabilities }\end{array}$ & $41(38.0)$ & $8(15.4)$ & $33(58.9)$ & $21.71 p<.000$ & $23(37.1)$ & $17(41.5)$ & $0.09 p=.760$ \\
\hline $\begin{array}{l}\text { People with cognitive } \\
\text { disabilities unrelated } \\
\text { to age }\end{array}$ & $30(28.3)$ & $8(16.3)$ & $22(38.6)$ & $6.44 p=.011$ & $17(28.3)$ & $12(29.3)$ & $0.01 p=.950$ \\
\hline $\begin{array}{l}\text { People of different } \\
\text { sexual orientation, } \\
\text { including LGBTI }\end{array}$ & $28(25.7)$ & $12(23.5)$ & $16(27.6)$ & $0.23 p=.629$ & $21(33.9)$ & $6(14.3)$ & $4.78 p=.029$ \\
\hline $\begin{array}{l}\text { Socially disadvantaged } \\
\text { people }\end{array}$ & $26(23.6)$ & $2(3.8)$ & $24(41.4)$ & $21.39 p<.000$ & $14(22.2)$ & $10(23.8)$ & $0.22 p=.640$ \\
\hline
\end{tabular}

Percentages for each survey item were calculated as valid percentage i.e. missing values were excluded

respondents noted more than one strategy. The most frequently reported active recruitment method was through other groups or services in the community. Other ways included approaching service users directly and through specific health service teams.

Table 4 Frequency of reported mechanisms used by health services for consumer partnering

\begin{tabular}{ll}
\hline $\begin{array}{l}\text { Mechanisms for partnering } \\
\text { (based on wording used by } \\
\text { respondents) }\end{array}$ & $\begin{array}{l}\text { N of responses to all } \\
\text { survey questions on } \\
\text { consumer partnering }\end{array}$ \\
\hline Community advisory committee & 146 \\
Representative at other committees & 124 \\
Surveys/interviews & 50 \\
Consumer focus groups & 35 \\
Via patient feedback & 20 \\
Representative at board & 14 \\
Via consumer groups & 14 \\
Presented/discussed at other committees & 13 \\
Reports to other committees and/or board & 11 \\
Policy documentation & 7 \\
Regular meetings with consumers & 7 \\
Via open forum & 5 \\
Discussed at meetings & 4 \\
Total number of free text responses & 450
\end{tabular}

${ }^{a}$ Number of qualitative responses indicates the frequency of each theme across nine questions related to consumer partnering activities. Some services were engaged in more than one activity therefore responses from services were coded multiple times
Reasons for not seeking inclusion of minority groups

Table 7 summarises the reasons given by respondents about why they did not seek inclusion of minority groups. A total of 276 responses were received. Some gave more than one reason. Some respondents considered it irrelevant or inappropriate for their organisation, while others suggested there are low numbers of people from minority groups in the local area, that they have limited resources to seek out participants, or there was a lack of interest from relevant groups.

\section{Discussion}

This is the first Australian survey of health services seeking information about partnering with consumers and efforts to include participants from minority groups. The NSQHS Standard Two requires that all Australian health organisations providing hospital or day surgery services partner with consumers and services undergo a regular accreditation process [3]. Given this imperative to partner, it might be assumed that all health services targeted would be making efforts in this domain.

Three key issues emerged: 1) while most services are partnering with consumers in various activities, the highest proportion of involvement appears to be through engagement in relatively operational or 'bolt-on' activities (e.g. advising on patient information or involvement in a specific consumer committee), rather than through apparently more systemic approaches (e.g. involving consumers in service design and workforce training activities) or activities affecting service strategy (e.g. 
Table 5 Frequency of comments describing partnering activities used by health services

\begin{tabular}{|c|c|c|}
\hline Partnering activities & $\begin{array}{l}\text { Number of free text } \\
\text { responses }\end{array}$ & Example of comments \\
\hline $\begin{array}{l}\text { Involved in reviewing and giving } \\
\text { feedback }\end{array}$ & 157 & $\begin{array}{l}\text { - Consumer representative reviews our patient feedback surveys and makes } \\
\text { recommendations } \\
\text { - Consumer partnership committee reviews and comments on quality } \\
\text { performance data and incident management. } \\
\text { - Review of clinical indicators and feedback on some strategies that could be } \\
\text { used to improve outcomes. } \\
\text { - Review of our acute health handbook. } \\
\text { - Reviews our patient information brochures for health literacy. }\end{array}$ \\
\hline Involved in service design & 40 & $\begin{array}{l}\text { - Redeveloping the site in the next } 2 \text { years and consumers have been involved } \\
\text { in a number of service delivery projects. } \\
\text { - Consumers involved in priority service design projects (e.g. Outpatients } \\
\text { Transformation, Nightlife, Culture Transformation). }\end{array}$ \\
\hline $\begin{array}{l}\text { Involved in planning (including the } \\
\text { types of activities) }\end{array}$ & 35 & $\begin{array}{l}\text { - Consumers on Board involved in service planning. } \\
\text { - Consumers are invited to participate in strategic planning days and workshops } \\
\text { with all CEO Executive and Dept. heads present, they are asked for input and } \\
\text { comment. Some suggestions are adopted into current strategic plan and } \\
\text { highlight areas requiring work. }\end{array}$ \\
\hline $\begin{array}{l}\text { Contributed to the design of } \\
\text { information/ brochures }\end{array}$ & 31 & $\begin{array}{l}\text { - Consumer committee review and advise on patient information brochures. } \\
\text { - Consumers have been used to design the Quality of Care report and provide } \\
\text { feedback on the website. }\end{array}$ \\
\hline Involving consumers in audits & 19 & $\begin{array}{l}\text { - Involved in audit of improvement activities such as the patient and carer escalation } \\
\text { project. } \\
\text { - Consumers audit some clinical data. } \\
\text { - Involved in bedside patient experience audits. }\end{array}$ \\
\hline Involved in decision making & 11 & $\begin{array}{l}\text { - Assisting in the design and selection of new patient and visitor furniture, soft } \\
\text { furnishings and décor. } \\
\text { - We have } 6 \text { co- design improvement projects running with consumer input. } \\
\text { - Involved in review of hospital signage, patient menu testing, implementing } \\
\text { medication management plan, creating patient information videos for website. }\end{array}$ \\
\hline Quality improvement activities & 8 & $\begin{array}{l}\text { - Included on quality projects - part of project team memberships. } \\
\text { - Monthly clinical audits, monitoring aspects of Excellent Care surveys monthly, } \\
\text { regular clinical safety and quality focused executive rounding is accompanied by } \\
\text { consumer advisors. }\end{array}$ \\
\hline
\end{tabular}

Total number of free text responses $\quad 301$

Table 6 Recruitment methods to include minority groups, reported by health services

\begin{tabular}{|c|c|c|}
\hline Active recruitment & Number & Example comments \\
\hline $\begin{array}{l}\text { Through other groups/ } \\
\text { services }\end{array}$ & 36 & $\begin{array}{l}\text { - Actively sought out local disability groups in community. } \\
\text { - We used local multicultural organisations and local Indigenous organisations to assist in providing } \\
\text { representatives on the consumer committee. }\end{array}$ \\
\hline Approached service users & 20 & $\begin{array}{l}\text { - We approached individuals in this category that have been patients at the hospital. } \\
\text { - We approached individuals who had been patients at the hospital/family of individuals that have } \\
\text { been patients at the hospital. }\end{array}$ \\
\hline Through service staff/teams & 17 & $\begin{array}{l}\text { - Cultural and linguistic diversity team in collaboration with our consumer engagement team do this } \\
\text { at our various facilities. } \\
\text { - We made contact with the Traditional owners and Elders via the hospital liaison team. We then had } \\
\text { a morning tea to introduce the Elders to the Chief Executive. }\end{array}$ \\
\hline $\begin{array}{l}\text { Community advisory } \\
\text { committee }\end{array}$ & 13 & $\begin{array}{l}\text { - We are a very diverse organization. Our community advisory committee has representation from key } \\
\text { community groups. }\end{array}$ \\
\hline $\begin{array}{l}\text { Targeted recruitment/ } \\
\text { advertising }\end{array}$ & 9 & $\begin{array}{l}\text { - Yes, again aim to increase this input. Posters across organisation advertising consumer register, } \\
\text { advertised in external newspapers. } \\
\text { - Advertise in ethnic media. }\end{array}$ \\
\hline Approached carers & 6 & $\begin{array}{l}\text { - Our Cognitive Impairment committee has sought the involvement of a carer of an individual with } \\
\text { dementia. }\end{array}$ \\
\hline Governance structures & 2 & $\begin{array}{l}\text { - Aboriginal Governance Committee is a Board sub-committee with Chair and representation from } \\
\text { the Aboriginal community. }\end{array}$ \\
\hline
\end{tabular}


Table 7 Reasons why health services did not seek inclusion from minority groups

\begin{tabular}{|c|c|c|}
\hline Reasons why services did not seek inclusion & Number & Example comments \\
\hline Not appropriate /relevant & 79 & $\begin{array}{l}\text { - Minimal relevance to our services. } \\
\text { - Not really relevant at the moment but if demand indicated we would look at it. }\end{array}$ \\
\hline Limited diversity & 61 & $\begin{array}{l}\text { - Limited diversity amongst patient group. } \\
\text { - People from diverse backgrounds form a very small part of our patient population. } \\
\text { Their needs are considered in different ways and on an individual basis. }\end{array}$ \\
\hline All welcome & 42 & $\begin{array}{l}\text { - We do not have a very culturally diverse demographic so while no one is excluded } \\
\text { we haven't focused on including any specific groups. } \\
\text { - Because everyone is welcomed regardless. }\end{array}$ \\
\hline Planned in future & 24 & $\begin{array}{l}\text { - Very difficult in our geographical area and the work that we undertake. However } \\
\text { there is plan to undertake in the next } 12 \text { months. } \\
\text { - Beginning to consider a strategy for this. No funding at this stage - challenges to } \\
\text { identify a feasible approach to targeted consultation. }\end{array}$ \\
\hline Current methods unsuccessful & 23 & $\begin{array}{l}\text { - Difficulty recruiting members for the committee. Have looked at cultural and ethnic } \\
\text { clusters within our region and have been unable to recruit anyone to date that is not } \\
\text { white Caucasian Australian. } \\
\text { - Difficulties in a small community but keep trying. }\end{array}$ \\
\hline Committee self nominates & 15 & - Committee members (consumers or carers) are self-nominating. \\
\hline Lack of resources & 14 & $\begin{array}{l}\text { - Lack the resources to specifically involve particular members of the community. } \\
\text { - Although we do have engagement with Indigenous communities, there is limited } \\
\text { engagement with other communities due to lack of an engagement framework and } \\
\text { resources. }\end{array}$ \\
\hline Identification challenge $\mathrm{a}^{\mathrm{a}}$ & 14 & $\begin{array}{l}\text { - No process for identifying or communicating with the LGBTI community. } \\
\text { - Not on purpose, we don't ask the sexual orientation of our patients. }\end{array}$ \\
\hline Lack of community interest & 4 & $\begin{array}{l}\text { - No interest from consumers to participate other than on the day of their appointment. } \\
\text { - Limited number of people interested in roles in small rural health service \& ageing } \\
\text { population. }\end{array}$ \\
\hline
\end{tabular}

${ }^{\mathrm{a}}$ Mostly in relation to question about the LGBTI community

strategic planning or governance); 2) there appears to be limited activity around inclusion of minority groups; 3 ) there appear to be differences in the activities of public versus private, and non-metropolitan versus metropolitan, services. These issues are discussed below.

\section{Most services are partnering in several activities - mostly using committees}

The majority of services are engaged in partnership with consumers (95\%) and used community advisory committees as a key mechanism. One of the requirements of the NSQHS [3] in relation to consumer partnership is 'establishing governance structures'. Forming a specific community advisory committee appears to be a relatively non-disruptive way for services to meet this requirement, by 'bolting-on' a new committee rather than taking steps to integrate consumers into existing committee structures and activities. This finding aligns with previous findings of the Australian Commission on Safety and Quality in Health Care [14] evaluation where involving consumers in committees was considered, by health services, to be one of the easiest consumer partnership activities.

Through involvement in a specific consumer advisory committee or being placed as a consumer representative on other committees, our findings show that consumers are drawn into various activities. However, these could be interpreted as being in relatively superficial areas of activity - such as providing feedback on patient information. There are different ways to view this situation. Established frameworks for analysing citizen involvement might understand this activity as 'consulting' [29] or 'participation as a means' [30] and thus relatively tokenistic and instrumental; with deeper structural and more system-wide involvement necessary to producing the empowered citizens and communities that bring population health impacts [31].

However, Tambuyzer and colleagues [32] highlight that, in consumer partnering, 'one size does not fit all' [p145]. Participation does not always have to aim for complex activities and there should be awareness that consumers may not desire to be involved in service strategy formulation or governance. It may boost consumers' confidence to work together as a group, rather than be spread as individuals across a range of activities. Tritter and McCallum [33] highlight that consumer partnering in health activities is a complex business - that different individuals will want to contribute in different ways - and that health organisations are best served if citizens provide a range of inputs from commentary to strategic and directional involvement.

This makes having a specific consumer committee a beneficial activity, but perhaps within a portfolio of optional activities for partnering. If a consumer committee 
is the main focus of activity, then this runs the risk of appearing to be an easily-established after-thought, bolted-onto rather than integrated into a health service organisation. O'Shea et al. [34] suggest that, if consumer partnering is about co-production of services rather than 'box-ticking' to say a consumer has been consulted, then health services should include consumers in a range of activities where their perspective is of equal value to health employees [34].

\section{Inclusion of minority groups is reported less}

Just under half of responding services had recruited consumer participants from minority groups. Inclusion of diverse participants is often highlighted as challenging in consumer partnering [35]. Nonetheless, we found several health services actively applying strategies to include minorities, including approaching other groups and services, their own service users and even targeted advertising. This shows that inclusion of minority groups is an issue acknowledged as significant by some services that have implemented strategies to specifically attract minority groups. These services may be early adopters, providing useful experience from which others could learn. By contrast, some respondents noted that participants from minority groups were not actively sought out because they already attained diversity due to the demographics of their location.

Some service respondents said they did not recruit from minority groups because it was irrelevant. Perhaps this is justifiable for some specialised services or for services located in areas with homogeneous populations. However, given research showing that minority groups tend to be under-represented in consumer partnering [36], it seems important for services to have robust evidence justifying non-inclusion of minority group participants. Other respondents highlighted difficulties in attracting minority group participants; for example, people from the LGBTI community in rural areas. This highlights a challenge in identifying participants with particular experiences without causing stigmatisation - an issue previously highlighted by other studies (e.g. [37]). Overall, it appeared that compared to other minority groups, less efforts were made to include socio-economically disadvantaged people. This could be because it is difficult to 'label' and specifically identify socially disadvantaged people for example, in advertising - because they are perceived to have more ambiguous distinguishing characteristics, compared with disability or ethnicity. That is, perhaps it is more culturally embedded in Australia, to identify (i.e. label as 'other') some minority groups, compared to others. There was less inclusion of minority groups in non-metropolitan areas, and this could be due to reticence to look for, identify and include minority group participants due to the close-knit nature of rural places [38].
One issue may be a lack of tools to inform Australian health services about strategies for inclusion of minority groups, including in different geographical settings where there may be fewer numbers of people belonging to minority groups. Technology is increasingly mooted as potentially useful for including diverse views - either to actively include diverse participants in conversations (e.g. using social media discussions); or establishing specialist discussion groups that can be followed on social media to engage with important topics [39]. The NHS England [16] guidance on engaging with minority groups, notes that giving multiple ways to partner is useful for engaging minority groups, with technology adoption as one useful option. However, considerable care has to be taken with considering technology as a solution because digital exclusion due to poverty, variable connectivity, illiteracy, communication challenges and limited cultural sensitivity still present considerable barriers [39]. Using technology did not arise at all as a strategy deployed by health services in our survey, which may suggest a gap for future study.

\section{Differences between types of services}

There was a significant association between public, as opposed to private, health services and consumer partnering activities; and a strong association between public health services and engagement with minority groups. This could be attributable to public services having to be more accountable for meeting public needs, as they are paid for by taxpayers. There is also evidence, particularly for small, non-metropolitan public health services, that they take considerable steps to build community inclusion and cohesion - so they are perhaps more culturally aligned with seeking inclusion of minority groups [40]. It could also be the case that public health services are more location-specific, embedded in the geographical communities, whose populations form strong connections to them. Private services tend to have wider reach, based more on volume of demand and patients' capacity to pay than proximity to community, potentially making it more difficult to attract volunteer consumer partners.

Non-metropolitan services were more engaged in consumer partnering than metropolitan services, but were less likely to include minority groups. Greater engagement in consumer partnering activity may reflect a closer alignment with principles of primary health care provision among rural health services. Primary care strongly emphasises the role of community participation and empowerment [30] and some studies of Australian rural health services have highlighted a specific mission regarding community capacity-building [41]. Less inclusion of people from minority groups potentially reflects the demographics of Australian rural areas which are traditionally less culturally diverse than metropolitan Australia [42]. The challenges of highlighting 'other-ness' in rural 
places, for the potential stigma it brings, has already been noted above. It is perhaps more risky to try to identify diverse people in rural areas, more risky for them to be engaged, and due to smaller overall numbers, there are likely to be fewer participants from each of the minority groups.

\section{Study limitations}

The study has limitations. There was uneven response across States and Territories, with highest numbers of responses from the States of Victoria and New South Wales. In relation to numbers distributed, there was poorest response from South Australia with only 15\% responding compared to a range of $21-33 \%$ for most other States/Territories. The uneven response means we know little about how the culture of State health service systems might influence consumer partnering.

The survey was limited to services providing hospital and day surgery services because these services are covered by the national standards. If primary health services and Aboriginal and Torres Strait Islander services were also specifically studied, there is potential that a range of different strategies and activities would be identified. A range of strategies and deep involvement of consumers were found by Freeman et al. [30] in a study of six Australian primary healthcare services, for example.

We restricted response options to 'yes', 'no' or 'don't know'. It might have been useful to provide a finer-grained scale so that we could establish the extent to which activities were being conducted, although some information was provided through the listing of activities by services where they took the time to do this. Providing a scale or more nuance around explaining activities could be useful in future research of this topic.

Findings might have limited transferability beyond the responding group. It is known that people are more likely to respond to surveys if the topic interests them (i.e. selection bias) - either because they are particularly affected by, or interested in, the items asked about. As people who respond almost certainly have different characteristics than those who do not, the results may be biased [43]. If the respondents are those that are most active and interested, then the findings could inflate the extent to which consumer partnering occurs. Innovators in consumer partnering may have self-selected to respond. Participants self-reported and the survey only accounts for CEOs' (or their representatives') perspectives. It is also possible that findings may be subject to response bias - given that the survey concerned compliance with standards, it is possible that respondents' subjective reports were more positive than an objective measurement would verify. Further research also considering perspectives of consumers and staff, at the same services as the CEOs, would be valuable in generating a more accurate picture.
Finally, a revised set of Australian NSQHS standards has just been published [44]. Regarding consumer partnering, these highlight consumer committees and consumer involvement in activities around health literacy as core partnering activities. They continue to highlight the importance of including minority groups. While in the aforementioned respects, the new standards appear sharper than previously, there remains a lack of clarity about the nature of partnering that health services should pursue beyond apparently easier to bolt-on, activities.

Given the limitations outlined, as an exploratory study - systematically examining for the first time, the extent of consumer partnering in Australian health organisations - we suggest the findings make a significant and novel contribution to the field.

\section{Conclusions}

This study represents a significant new contribution to the international literature on consumer partnering, for research and practice communities, as it quantifies partnering strategies in use in one developed country setting. Our findings enable identification of strategies, perceived best practice and highlight difficulties in implementing partnering. In particular, we present novel findings about strategies to include participants from minority groups. While study findings are from Australia, they are significant for informing international policy and practice about the strategies, and key remaining challenges, for hospital services partnering with consumers.

We found many services implementing strategies for consumer partnering that were easily 'bolted-on' to existing structures rather than integrated into the service, while others were employing partnering for more strategic aspects and making efforts to include minority groups. These latter services provide examples of good practice models and strategies that could be used by other services. Future research should also consider consumer and healthcare staff perspectives and probe the potential of digital participation as one method for consumer partnering, including use of social media. Examining participation using digital technologies seems a gap as no services in our study mentioned using digital participation.

\section{Additional file}

Additional file 1: Health Services Partnering with Consumers. (DOCX $16 \mathrm{~kb}$ )

\section{Abbreviations}

ACSQHC: Australian Commission on Safety and Quality in Health Care; CEO: Chief Executive Officer; LGBTI: Lesbian, gay, bisexual, trans and intersex; NHS: National Health Service; NSQHS: National Safety and Quality Health Service; UK: United Kingdom; WHO: World Health Organisation 


\section{Acknowledgements}

The authors thank all of those who responded to the survey.

\section{Funding}

The study received no external funding and was supported through La Trobe and Swinburne Universities.

\section{Availability of data and materials}

The datasets used and analysed during the current study are available from the corresponding author on reasonable request.

\section{Authors' contributions}

The study was designed by JF, CB, HD, AK, RH. HD and RH were responsible for identifying the sample, emailing the survey and managing returns. $\mathrm{RH}$ prepared data for analysis. All authors were involved in data analysis. KC, JF, HD and CB prepared initial draft of article. All authors read and approved final manuscript.

\section{Ethics approval and consent to participate}

This study has ethical approval from the La Trobe University Human Research Ethics Committee (S16-129). A consent statement and participant information sheet was included in the online survey. Completion of the online survey signified consent to participate.

\section{Consent for publication}

Not applicable.

\section{Competing interests}

The authors declare that they have no competing interests.

\section{Publisher's Note}

Springer Nature remains neutral with regard to jurisdictional claims in published maps and institutional affiliations.

\section{Author details}

'Social Innovation Research Institute, Swinburne University of Technology, John Street, Hawthorn, Melbourne, Australia. ${ }^{2}$ Living with Disability Research Centre, La Trobe University, Bundoora, Melbourne, Australia. ${ }^{3}$ Centre for Social Impact, Swinburne University of Technology, John Street, Hawthorn, Melbourne, Australia. ${ }^{4}$ College of Medicine and Dentistry, James Cook University, Townsville, Australia. ${ }^{5}$ Australian Institute of Tropical Health and Medicine, James Cook University, QLD, Townsville, Australia. 'a Trobe Rural Health School, La Trobe University, Bendigo, Australia. ${ }^{7}$ Raven Consulting Group, Unit 4, 62 Wattletree Road, Armadale Vic, Melbourne 3143, Australia.

\section{Received: 19 December 2017 Accepted: 30 July 2018}

\section{Published online: 10 August 2018}

\section{References}

1. WHO. Ninth futures forum on health systems governance and public participation. Copenhagen: WHO; 2006

2. WHO. Declaration of Alma-Ata international conference on primary health care, Alma-Ata, USSR, 6-12 September 1978. Development. 2004:47(2):159-61.

3. Australian Commission on Safety and Quality in Health Care. Safety and quality improvement guide standard 2: partnering with consumers. Sydney: ACSQHC; 2012.

4. de Freitas C, Martin G. Inclusive public participation in health. Policy, practice and theoretical contributions to promote the involvement of marginalised groups in healthcare. Soc Sci Med. 2015;135:31-9.

5. Australian Commission on Safety and Quality in Health Care. National safety and quality health service (NSQHS) standards. Sydney: ACSQHC; 2012.

6. Australia Government Department of Health. PHN commissioning Designing and contracting services guidance. 2016. http://health.gov.au/ internet/main/publishing.nsf/Content/ E11D6513E6583EA1CA2580D4000F0A70/\$File/ PHN\%20Designing\%20and\%20Contracting\%20Services\%20v0.1.pdf . Accessed 17 Dec 2017

7. NHS England. Patient and public participation policy. Leeds: NHS England; 2017.
8. Australian Commission on Safety and Quality in Health Care. Safety and quality improvement quide standard 1: governance for safety and quality in health service organisations. Sydney: ACSQHC; 2012.

9. Holman DV. The relational bent of community participation: the challenge social network analysis and Simmel offer to top-down prescriptions of 'community'. Community Dev J. 2015;50(3):418-32.

10. Chessie K. Health system regionalization in Canada's provincial and territorial health systems: do citizen governance boards represent, engage, and empower? Int J Health Serv. 2009;39(4):705-24.

11. Stewart E. Scotland's NHS: citizen participation and mutuality in Scottish health policy. In: Publics and their health systems. London: Palgrave MacMillan; 2016. p. 19-35.

12. Gill SD, Gill M. Partnering with consumers: national standards and lessons from other countries. Med J Aust. 2015;203(3) https://doi.org/10.5694/mja14.01656

13. Taylor J, Wilkinson D, Cheers B. Working with communities in health and human services. South Melbourne: Oxford University Press; 2008.

14. Australian Commission on Safety and Quality in Health Care. NSQHS Standards in 2013: transforming the safety and quality of health care. Sydney: ACSQHC; 2014.

15. de Freitas C. Aiming for inclusion: a case study of motivations for involvement in mental health-care governance by ethnic minority users. Health Expect. 2015;18(5):1093-104.

16. NHS England. NHS England and patient and public participation equality and health inequalities - full analysis and associated resources. Leeds: NHS England; 2016.

17. Kline R. The "snowy white peaks" of the NHS: a survey of discrimination in governance and leadership and the potential impact on patient care in London and England. 2014 https://www.mdx.ac.uk/news/2014/04/thesnowy-white-peaks-of-the-nhs. Accessed 14 Dec 2017.

18. UK Government. Equality act 2010. Westminster: UK Government; 2010.

19. Marmot M. The health gap: the challenge of an unequal world: the argument. Int J Epidemiol. 2017:46(4):1312-8.

20. Trollor J, Srasuebkul P, Xu H, Howlett S. Cause of death and potentially avoidable deaths in Australian adults with intellectual disability using retrospective linked data. BMJ Open 2017; 7(2); doi.org/https://doi.org/10. 1136/bmjopen-2016-013489.

21. Shimmin C, Wittmeier KDM, Lavoie JG, Wicklund ED, Sibley KM. Moving towards a more inclusive patient and public involvement in health research paradigm: the incorporation of a trauma-informed intersectional analysis. BMC Health Serv Res. 2017;17(1):539. https://doi.org/10.1186/s12913-0172463-1.

22. van der Greft S, Droogleever Fortuijn J. Multiple disadvantage of older migrants and native Dutch older adults in deprived neighbourhoods in Amsterdam, the Netherlands: a life course perspective, GeoJournal 2017; 82: 415; doi.org/https://doi.org/10.1007/s10708-015-9691-x.

23. Frawley P, Bigby C. Inclusion in political and public life: the experiences of people with intellectual disability on government disability advisory bodies in Australia. J Intellect Develop Disabil. 2011;36(1):27-38.

24. Farmer J, Currie M, Kenny A, Munoz SA. An exploration of the longer-term impacts of community participation in rural health services design. Soc Sci Med. 2015;141:64-71.

25. Lick DJ, Durso LE, Johnson KL. Minority stress and physical health among sexual minorities. Perspect Psychol Sci. 2013:8(5):521-48.

26. Martin, G. 'Ordinary people only': knowledge, representativeness, and the publics of public participation in healthcare. Soc Health \& IIIn. 2008;30(1):35-54.

27. Shih $\mathrm{T}-\mathrm{H}$, Fan $\mathrm{X}$. Comparing response rates in e-mail and paper surveys: a meta-analysis. Educ Res Rev. 2009;4:26-40.

28. Morgan DL. Qualitative content analysis: a guide to paths not taken. Qual Health Res. 1993;3(1):112-21.

29. Arnstein SR. A ladder of citizen participation. J Am Plan Assoc. 1969;35(4): $216-24$.

30. Freeman T, Baum FE, Jolley GM, Lawless A, Edwards $T$, Javanparast $\mathrm{S}$, Ziersch A. Service providers' views of community participation at six Australian primary healthcare services: scope for empowerment and challenges to implementation. The Int J Health Plan M. 2016;31:E1-21.

31. Laverack $G$, Labonte R. A planning framework for community empowerment goals within health promotion. Health Policy Plan. 2000; 15(3):255-62.

32. Tambuyzer E, Pieters G, Van Audenhove C. Patient involvement in mental health care: one size does not fit all. Health Expect. 2014;17(1):138-50. 
33. Tritter J, McCallum A. The snakes and ladders of user involvement: moving beyond Arnstein. Health Policy. 2006;76:156-68.

34. O'Shea A, Chambers M, Boaz A. Whose voices? Patient and public involvement in clinical commissioning. Health Expect. 2017;20(3):484-94.

35. Maguire K, Britten N. "How can anybody be representative for those kind of people?" Forms of patient representation in health research, and why it is always contestable. Soc Sci Med. 2017;183:62-9.

36. Ocloo J, Matthews R. From tokenism to empowerment: progressing patient and public involvement in healthcare improvement. BMJ Qual Saf. 2016;25: 626-32.

37. Robinson N, Lorenc A. 'No one wants to be the face of herpes London': a qualitative study of the challenges of engaging patients and the public in sexual and reproductive health and HIV/AIDS services. Health Expect. 2015; 18(2):221-32.

38. Lyons A, Hosking W, Rozbroj T. Rural-urban differences in mental health resilience, stigma, and social support among young Australian gay men. J Rural Health. 2015;31(1):89-97.

39. Thomas J, Barraket J, Wilson C, Ewing S, MacDonald T, Tucker J, Rennie E. Measuring Australia's digital divide: the Australian digital inclusion index. Melbourne: Telstra; 2017.

40. Prior M, Farmer J, Godden D, Taylor J. More than health: the added value of health care to rural communities in Scotland and Australia. Health Place. 2010;16:1136-44

41. Farmer J, Davis H, Blackberry I, de Cotta T. Assessing the value of rural community health services. Aust J Prim Health. 2018;24(3):221-6.

42. Forrest J, Dunn K. Cultural diversity, racialisation and the experience of racism in rural Australia: the south Australian case. J Rural Studies. 2013;30:1-9.

43. Eysenbach $G$, Wyatt J. Using the internet for surveys and Health Research. J Med Internet Res. 2002;4(2):e13. https://doi.org/10.2196/jmir.4.2.e13.

44. Australian Commission on Safety and Quality in Health Care. National safety and quality in health service standards. Sydney: ACSQHC; 2017.

Ready to submit your research? Choose BMC and benefit from:

- fast, convenient online submission

- thorough peer review by experienced researchers in your field

- rapid publication on acceptance

- support for research data, including large and complex data types

- gold Open Access which fosters wider collaboration and increased citations

- maximum visibility for your research: over $100 \mathrm{M}$ website views per year

At $\mathrm{BMC}$, research is always in progress.

Learn more biomedcentral.com/submissions 